\title{
Inferring habitat and feeding behaviour of early Miocene notoungulates from Patagonia
}

\author{
GUILLERMO H. CASSINI, MANUEL MENDOZA, SERGIO F. VIZCAÍNO AND M. SUSANA BARGO
}

\section{LETHAIA}

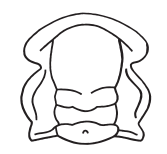
Cassini, G.H., Mendoza, M., Vizcaíno, S.F. \& Bargo, M.S. 2011: Inferring habitat and
feeding behaviour of early Miocene notoungulates from Patagonia. Lethaia, Vol. 44 ,
pp. 153-165.

Notoungulates, native fossil mammals of South America, have been usually studied from a taxonomic point of view, whereas their palaeobiology has been largely neglected. For example, morpho-functional or eco-morphological approaches have not been rigorously applied to the masticatory apparatus to propose hypothesis on dietary habits. In this study, we generate inferences about habitat and feeding preferences in five Santacrucian genera of notoungulates of the orders Typotheria and Toxodontia using novel computer techniques of knowledge discovery. The Santacrucian (Santa Cruz Formation, late-early Miocene) fauna is particularly appropriate for this kind of studies due to its taxonomic richness, diversity, amount of specimens recorded and the quality of preservation. Over 100 extant species of ungulates, distributed among 13 families of artiodactyls and perissodactyls, were used as reference samples to reveal the relationships between craniodental morphology and ecological patterns. The results suggest that all Santacrucian notoungulates present morphologies characteristic of open habitats' extant ungulates. Although the Toxodontia exhibits the same morphological pattern of living mixed-feeders and grazers, the Typotheria shows exaggerated traits of specialized grazer ungulates. $\square \mathrm{Cra}$ niodental morphology, ecomorphology, fossil ungulates, knowledge discovery, South America.

Guillermo H. Cassini [gcassini@fcnym.unlp.edu.ar], División Paleontología Vertebrados, Museo de La Plata, Paseo del Bosque s/n, B1900FWA La Plata, Argentina; Manuel Mendoza [mmendoza@fulbrightmail.com], Centro Oceanográfico de Murcia, Instituto Español de Oceanografía. Varadero 1, E-30740 San Pedro del Pinatar, Murcia, Spain; Sergio F. Vizcaino [vizcaino@fcnym.unlp.edu.ar] and M. Susana Bargo [msbargo@fcnym.unlp.edu.ar], División Paleontología Vertebrados, Museo de La Plata, Paseo del Bosque s/ $n$, B1900FWA La Plata, Argentina; manuscript received on 17/02/2010; manuscript accepted on 07/05/2010.

Notoungulata constitutes the most abundant and diverse clade of endemic South American ungulates, both taxonomically and morphologically (Simpson 1936; Patterson \& Pascual 1972; Cifelli 1993). Notoungulates are recorded throughout the Cenozoic, from the late Palaeocene to the late Pleistocene (Bondesio 1986; Croft 1999). The group reaches its greatest taxonomic richness (at the genus level) during the Palaeogene, gradually diminishing throughout the Neogene with forms that become progressively more specialized, until their extinction by the late Pleistocene-early Holocene (see Bond et al. 1995).

Following Billet (2010), the clade comprises two monophyletic groups: Toxodontia and Typotheria plus the basal notoungulate family Henricosborniidae, and a clade comprising Notostylops as the sister group of Pyrotheria (before considered as a separate order). Toxodonts include large (i.e. above $44 \mathrm{~kg}$, sensu Martin \& Steadman 1999) to very large animals (including strictly megammamals, i.e. $1000 \mathrm{~kg}$ or more), and are sometimes compared with hippos or rhinos, due to their inferred general appearance and the grinding pattern of molar crowns (Ameghino 1907; Scott 1912; Bond 1999). Typotheres are small-to-medium size mammals, mostly described as rodent-like in overall form, although different families resemble living capybaras (Mesotheriidae), hares (Hegetotheriidae), hyraxes (Interatheriidae) and small deer (Ameghino 1889; Sinclair 1909; Bond et al. 1995; Croft 1999; Reguero et al. 2007).

In both toxodonts and typotheres, there is an apparent tendency to evolve from generalized masticatory apparatus with complete dentition, without diastema and brachyodont cheek teeth, to very specialized forms including, for instance, hypertrophied incisors, simplified crown patterns and ever-growing (hypselodont) cheek teeth (Ameghino 1887, 1894; Scott 1937; Simpson 1967; Cifelli 1985). Some phylogenetic studies suggest that hypselodonty probably evolved at least four times within the Notoungulata in the Toxodontidae, Interatheriidae, Mesotheriidae and Hegetotheriidae (Croft \& Weinstein 2008). The 
palaeobiological implications of this morphological diversity and the relationship between form and function have not been analysed rigorously before, and the dietary inferences have been mostly limited to broad generalizations.

The Santacrucian mammalian fauna (Santa Cruz Formation, late-early Miocene) along the Atlantic coast of southern Patagonia is particularly appropriate for this kind of study due to its taxonomic richness, diversity, amount of specimens recorded and quality of preservation (see Vizcaíno et al. 2006, 2010; and references therein). Among notoungulates, the Toxodontia are represented by three genera: Nesodon, Adinotherium (Toxodontidae, Nesodontinae; Fig. 1A, B) and Homalodotherium (Homalodotheriidae). Calculating body mass using the mean of output of the allometric equations for 'all ungulates' proposed by Janis (1990a), Homalodotherium and Nesodon are among the largest ungulates from the
Santa Cruz beds ( 350 and $550 \mathrm{~kg}$ respectively), only being surpassed by the astrapothere Astrapotherium $(\sim 1000 \mathrm{~kg})$, whereas Adinotherium is rather smaller $(\sim 120 \mathrm{~kg})$. Nesodon, Adinotherium and Homalodotherium species have complete dentition without diastema and large masseteric and temporal muscles attachment areas. Nesodon and Adinotherium have hypertrophied lateral incisors and high-crowned of finite growth cheek teeth (protohypsodonty, sensu Mones 1982). The Santacrucian Typotheria are small-sized animals represented by Protypotherium, Interatherium (Interatheriidae; Fig. 1C, D), Hegetotherium and Pachyrukhos (Hegetotheriidae; Fig. 1E, F). Calculating body masses as decribed above, Hegetotherium and Pachyrukhos are respectively the largest $(\sim 14 \mathrm{~kg})$ and the smallest $(\sim 2.8 \mathrm{~kg})$ examples. Among interatheriids, Protypotherium species ( $\sim 4.5$ $\mathrm{kg}$ for the smaller Protypotherium attenuatum and approximately $8.5 \mathrm{~kg}$ for the largest Protypotherium
A

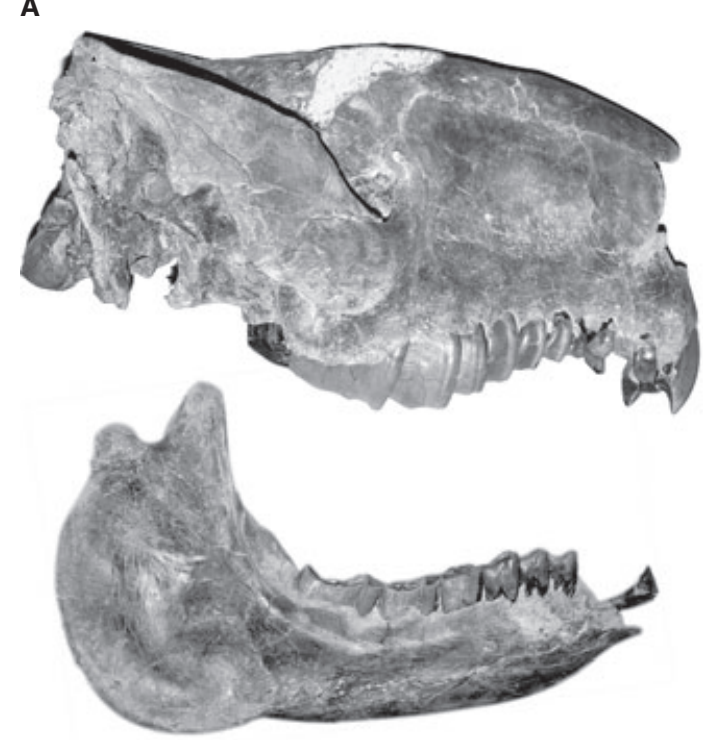

B

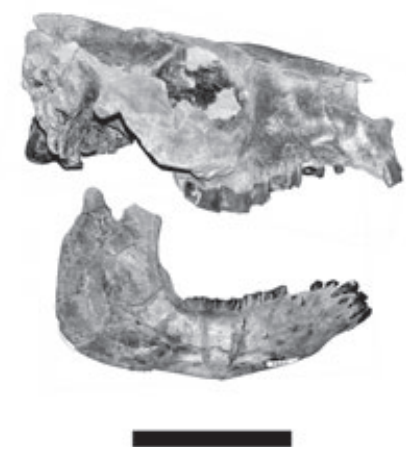

C

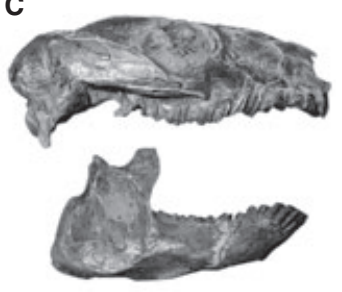

D
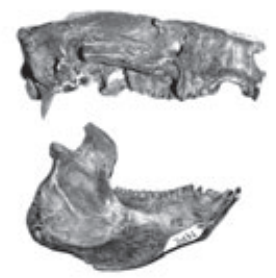

E

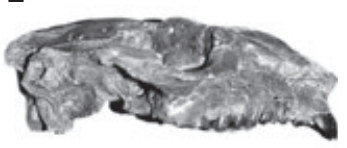

$\mathbf{F}$

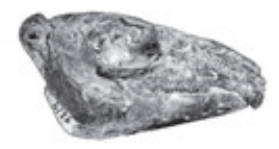

Fig. 1. Skull and mandible of Santacrucian notoungulates genera included in this study. Toxodontids: A, Nesodon MPM-PV 3659; B, Adinotherium MPM-PV 3532 and 3666. Typotheres: C, Protypotherium AMNH 9868; D, Interatherium MPM-PV 3471; E, Hegetotherium MPM-PV 3526; and F, Pachyrukhos AMNH 9219. Scale bar $10 \mathrm{~cm}$. 
australe) are larger than Interatherium $(\sim 3.5 \mathrm{~kg})$. Interatheriids include species with complete dentition and without diastema or hypertrophied incisors. Thus, their incisors are all the same width. In hegetotheriids, the upper and lower central incisors are hypertrophied, and the lateral incisors and canines are atrophied, resulting in a functional diastema in Hegetotherium, and an anatomical diastema with missing teeth in Pachyrukhos. In all these taxa, cheek teeth are high-crowned and ever-growing (euhypsodonty, sensu Mones 1982), and the masseteric muscle areas of attachment are larger than the temporal ones.

All genera analysed in this study have been traditionally considered mostly herbivores. Following Scott (1937), and based primarily on the high-crowned cheek teeth, they were considered inhabitants of open plains and other open-habitat, eating mostly grasses (Patterson \& Pascual 1968; Cifelli 1985; Billet et al. 2009). Bond (1986) and Tauber (1997b) also supported the grazers hypothesis based on the degree of hypsodonty and incisor morphology. With reference to Nesodon and Adinotherium, Madden (1997) proposed that the most complex molar crowns would have provided great shearing ability among toxodontids allowing them to break down the grasses more easily. However, Townsend \& Croft (2008) using a micro-wear approach for three genera of Santacrucian notoungulates disagreed the preceding dietary inferences. They conclude that Nesodon imbricatus was a leaf browser that focused more on hard browsing, including, potentially, bark consumption; Adinotherium ovinum was a pure leaf browser; and Protypotherium was a traditional browser that took both soft browse and soft fruits. Since Townsend \& Croft (2008), no other ecomorphological studies on craniomandibular morphology have been carried out in this group.

Contrarily, the relationship between habitat preference, diet and craniodental morphology in living ungulates has been intensively studied using different statistical approaches (Gordon \& Illius 1988; Solounias \& Dawson-Saunders 1988; Janis 1990b; Spencer 1995; Pérez-Barbería \& Gordon 1999; Mendoza et al. 2002). Mendoza \& Palmqvist (2008) show that novel machine-learning techniques of knowledge discovery (i.e. decision trees) were powerful tools for ecomorphological approaches. In this study, we apply the same techniques of knowledge discovery to identify new morphological patterns and infer the habitat and feeding behaviour of the notoungulates from the Santacrucian mammal assemblage. In doing so, species from two orders of living ungulates, Artiodactyla and Perissodactyla, were used as a reference. We assumed then that the morphological solutions present in both
Artiodactyls and Perissodactyls were also achieved by notoungulates.

The Principle of Actualism is applied, assuming that some biomechanical laws have constrained in the same manner the evolution of the craniodental structure of these three taxonomic groups, leading to the convergence of common morphological patterns. However, when the phylogenetic legacy is different, and the starting morphology varies, the same biomechanical laws can be upheld with different strategies, associated to different morphological patterns.

\section{Material and methods}

\section{Abbreviations}

AMNH: American Museum of Natural History, New York, USA; MACN: Museo Argentino de Ciencias Naturales 'Bernardino Rivadavia', Buenos Aires, Argentina; MLP: Museo de La Plata, La Plata, Argentina; MPM-PV: Museo Regional Provincial Padre 'M. J. Molina', Río Gallegos, Argentina; YPM-PU: Yale Peabody Museum, New Haven, USA.

\section{Data}

Forty-seven specimens of notoungulates from the Santa Cruz Formation (late-early Miocene) were analysed. Only specimens with no or little apparent deformation were measured. They include 20 toxodontids (13 specimens of Nesodon and seven Adinotherium), and 27 typotheres (10 specimens of Protypotherium, 11 Interatherium, 3 Hegetotherium and 3 Pachyrukhos) (see Table 1).

One-hundred and nineteen extant species of artiodactyls and perissodactyls, distributed among 13 families, taken from Mendoza et al. (2002), were used to analyse the relationship between the craniodental morphology of ungulates and their ecological adaptations (i.e. habitat and feeding behaviour).

Fourteen craniodental measurements, and the hypsodonty index (HI) were used in the analyses (Fig. 2). The length of diastema (JLB) was measured from the base of the third incisor to the first premolar (see Mendoza et al. 2002, table 2) in extant ungulates and the only notoungualte with diastema Pachyrukhos. The total length of the jaw (JAW) was obtained summing JLB (when present), JMA, LMRL and LPRL (Fig. 2).

The HI of notoungulates was achieved following Janis (1988), i.e. crown height ratio of $\mathrm{m} 3$ calculated as the crown height (taken from RX-radiography) divided by the labio-lingual width of the tooth. For the HI, only the well-preserved and complete 
Table 1. List of Notoungulata skulls examined.

\begin{tabular}{|c|c|}
\hline \multicolumn{2}{|l|}{ Toxodontia } \\
\hline \multicolumn{2}{|l|}{ Toxodontidae } \\
\hline Adinotherium & $\begin{array}{l}\text { AMNH: 9141; 9517; MACN-SC: 4355; MPM-PV: 3667; } 3668 \\
\text { YPM-PU: } 1503 \cdot 15136\end{array}$ \\
\hline Nesodon & $\begin{array}{l}\text { AMNH: } 9128 ; 9168 ; 9192 ; 9510 ; \text { MACN-A: 775; 5145; MLP: } 12-250 \\
\text { YPM-PU: } 15000 ; 15215 ; 15256 ; 15260 ; 15336 ; 15492\end{array}$ \\
\hline \multicolumn{2}{|l|}{ Typotheria } \\
\hline \multicolumn{2}{|l|}{ Interatheriidae } \\
\hline Interatherium & $\begin{array}{l}\text { AMNH: 9483; MPM-PV: 3469; 3471; 3527; } 3528 \\
\text { YPM-PU: } 15100 ; 15296 ; 15300 ; 15401 ; 15554\end{array}$ \\
\hline Protypotherium & $\begin{array}{l}\text { AMNH: 9187; 9565; MACN-A: 3920; } 3991 \\
\text { MPM-PV: 3470; 3530; 3531; 3661; YPM-PU: 15386; } 15828\end{array}$ \\
\hline \multicolumn{2}{|l|}{ Hegetotheriidae } \\
\hline Hegetotherium & AMNH: 9159; MPM-PV: 3481; YPM-PU: 15298; 15542 \\
\hline Pachyrukhos & AMNH: 9219; 9283; YPM-PU: 15744 \\
\hline
\end{tabular}

mandibles were used, which correspond to 17 MPMPV specimens. Janis (1988) procedure implies measuring fully erupted but still unworn m3. However, in the fossil record, it is highly improbable to find specimens with a tooth crown fully formed but unworn, making nearly impossible to examine variation in crown height between unworn and worn $\mathrm{m} 3$. Therefore, we assumed that, in euhypsodont notoungulates, the HI does not vary significantly during the lifespan of $\mathrm{m} 3$, being comparable with the HI from Janis (1988).

The HI is a size-independent variable, but the other measurements used were size-adjusted by dividing each of them by the lower molar tooth row length, measured along the base of the teeth (see details in Mendoza \& Palmqvist 2006).

\section{Analyses}

Two computer techniques of knowledge discovery were used: (1) discriminant analysis; and (2) classification trees. Discriminant analysis is a classical technique of multivariate statistics that allows classifying new samples within predefined groups using the discriminant functions adjusted for maximizing the between-groups to within-groups ratio of variance. In this contribution, we mainly use discriminant analysis as a technique of knowledge discovery (Cios et al. 1998). Classification trees, developed by Breiman et al. (1984), are a knowledge discovery technique (Larose 2004) that stems from the realm of machine learning (see Michie et al. 1994). Classification trees are nonparametric models. Some of their advantages are that they look at variables hierarchically rather than simultaneously, they are easy to interpret and they do not assume that the dependent variable follows any given distribution.

In this study, we follow the approach applied by Mendoza (2007) and Mendoza \& Palmqvist (2008), with the goal of better understanding the relationship between the skeleton morphology and their ecological adaptations in living ungulates. The 'discovered' knowledge is then used to infer the habitat and feeding behaviour of extinct ungulates not closely related to living forms. In the extinct taxa, the morphological evidence is restricted to the measurements available on the specimens; therefore, depending on the variables related to each ecological pattern, different specimens could be analysed.

For the first set of analyses, performed to characterize types of habitat, species were classified among the following three categories (Mendoza et al. 2005): (1) open habitats (i.e. treeless or scarcely wooded savannas, grasslands, dry deserts and semi-desert steppes); (2) mixed habitats (i.e. wooded savannas, bush land, open forests and species dwelling both in closed and open habitats); and (3) closed habitats (i.e. closed woodlands, riverine, moist deciduous and evergreen forests). Fifty-eight of the 119 living ungulate species included in this study were categorized as open habitats, 30 as mixed habitats and 31 as closed forested habitats. Mendoza \& Palmqvist (2008) interpreted JLB to be the best measurement of the jaw, together with $\mathrm{HI}$, for discriminating species from open and mixed habitats. As mentioned above, Santacrucian notoungulates do not have diastema (JLB). Hence, the other variables that also contribute to the length of the jaw, as well as the total length of the jaw, were analysed to evaluate whether they could be used instead of JLB.

As all Santacrucian notoungulates studied were characterized as preferring open or mixed habitats (see Results), we carried a second set of analyses in which extant species from closed habitats were not included. The remaining 88 species from open and mixed habitats were further subdivided according to their feeding behaviour as grazers or non-grazers. Only 31 living species that consume a high percentage of grass, which does not highly fluctuate through the year or between different localities, were classified as 

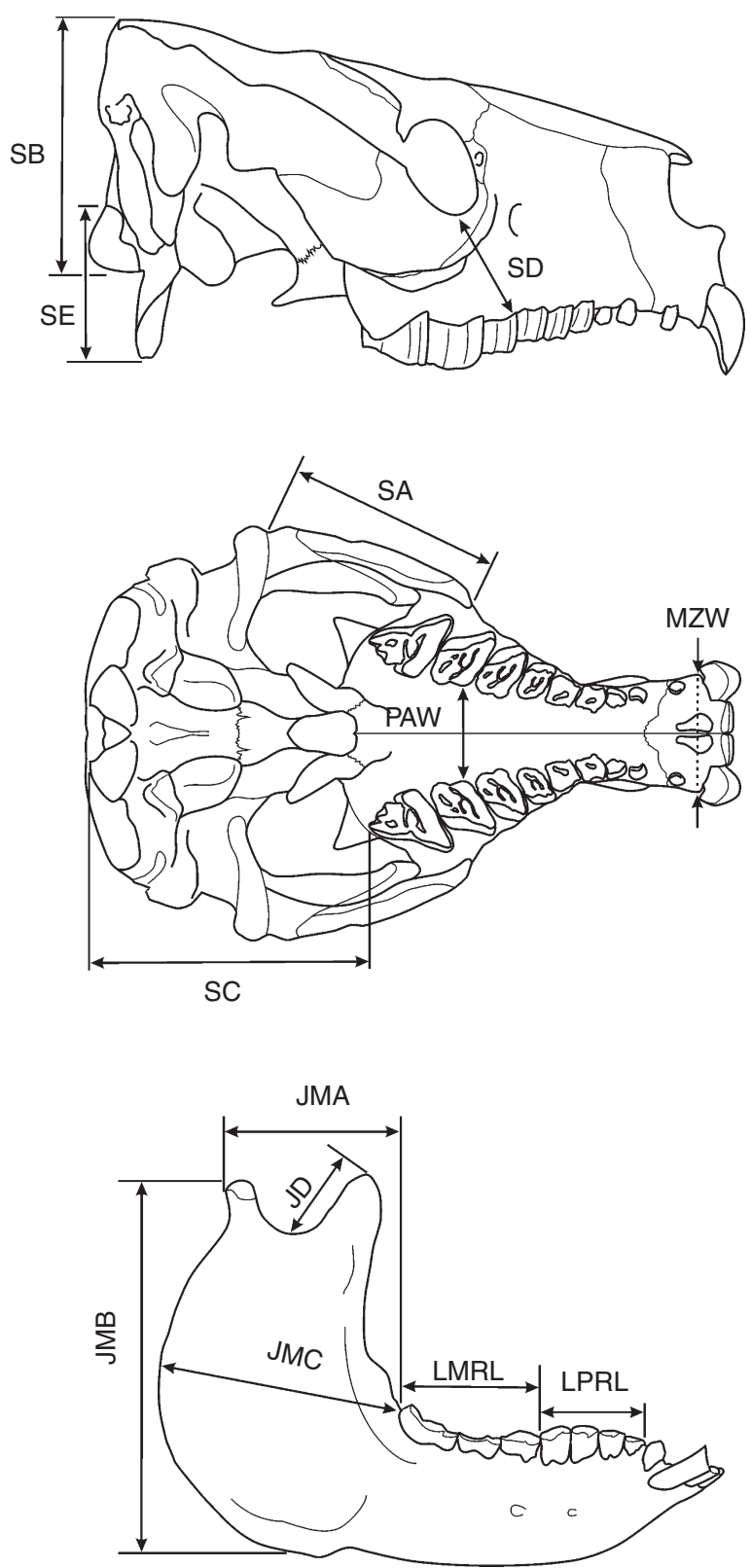

Fig. 2. Skull of Adinotherium with selected measurements used in this study. SA, length of the masseteric fossae; SB, occipital height; SC, length of the posterior portion of the skull; SD, depth of the face under the orbit; SE, length of the paraoccipital process; MZW, muzzle width; PAW, palatal width; JMA, posterior jaw length; JMB, depth of mandibular angle; JMC, maximum width of the mandibular angle; JD, length of the coronoid process; LMRL, lower molar tooth row length; LPRL, lower premolar tooth row length (see details in Mendoza et al. 2002).

grazers. Among the remaining species, 52 are mixed feeders that consume grass and dicotyledonous plants depending on their availability and five species mainly browse, from which three dwell in open habitats, in spite of being browsers.

The probability of obtaining a good discrimination between the groups compared merely by chance increases with the number of variables involved.
Therefore, only patterns that were found consistently based on limited combinations of variables were considered here.

Starting from 14 measurements, there are 455 possible combinations involving three or fewer of them. Knowledge discovery techniques were used then to identify those combinations of three or less variables that allow a better characterization of the ecological groups. The region occupied by each group in the space defined by a combination of few variables, subspaces of the full morphospace defined by whole 14 variables, constitute the morphological patterns that characterize each group (Mendoza 2007). The position of each extinct species in these subspaces, optimized for the task of group characterization, was carefully analysed to infer their habitat and feeding behaviour.

\section{Results}

\section{Inferences about habitat}

From the whole variables of the jaw that could be used instead of JLB to discriminate habitat preference, the relative length of the whole jaw (JAW) was the best to characterize species adapted to forage in open and mixed habitats. In the same way that JLB, the HI that allows distinguishing open-habitat species from those of mixed habitats, increases with JAW (see Fig. 3). Consequently, we develop here a Habitat Preference Index (HPI $=\mathrm{HI} / 1.4 \mathrm{JAW}-2.4)$, which combined with $\mathrm{HI}$ alone allows the characterization of habitat preference of the extant ungulates.

Mendoza \& Palmqvist (2008) showed that living ungulates from closed forested habitats have values of HI lower than 2. We find now that: (1) species dwelling mixed habitats have values of $\mathrm{HI}$ between 2 and 4, and values of HPI $<1$; and (2) species from open habitats also have values of $\mathrm{HI}>2$ and values of HPI $>1$. There are very few exceptions (see Fig. 3 and Discussion and conclusions section), in which species dwelling open habitats have HPI values lower that 1, six of seven species of Equus included in the database were not depicted in Fig. 3 in order to increase its resolution, given that they have very long jaws (5.54-6.12). The three species with the longest jaw have HPI values slightly lower than 1 (0.94-0.97), but they could not be mischaracterized as mixed habitat species because their HI values $(5.79-5.83)$ are much higher than 4 , the maximum value observed in the living ungulates dwelling mixed habitats.

Among typotheres, Protypotherium specimens show a little higher hypsodonty $(\mathrm{HI} \sim 4$; Table 2$)$, but most of them are also placed on the left-bottom region of 


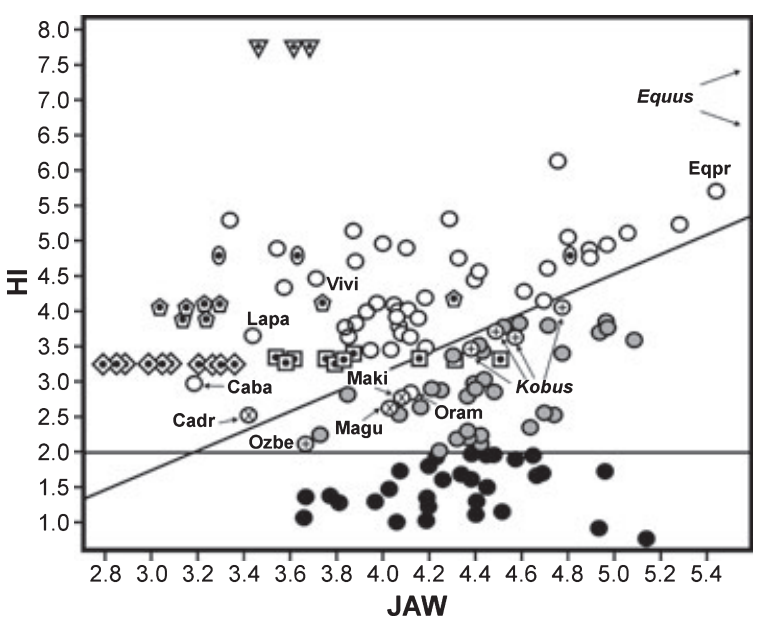

Fig. 3. Distribution of 119 extant ungulates and 26 notoungulates in the morphospace depicted by the hypsodonty index (HI) and the relative length of the jaw (JAW), which allows the characterization of the craniodental morphology of species from open habitats (white symbols), mixed habitats (grey symbols) and closed habitats (black symbols). Notoungulata (dotted symbols): Interatherium (squares), Nesodon (rhombus), Protypotherium (pentagons), Adinotherium (ovoids) and Hegetotherium (inverse triangles); extant ungulates: Camelus bactrianus (Caba), Camelus dromedarius (Cadr), Lama pacos (Lapa), Lama guanicoe (Lagu), Vicugna vicugna (Vivi) and Oreamnos americanus (Oram); water-associated habitat species (symbols with a plus sign): Ozotoceros bezoarticus (Ozbe), and four species from the genus Kobus; browsers from open habitats (symbols with a cross): Madoqua guentheri (Magu) and Madoqua kirkii (Maki).

the morphospace depicted by HI and JAW, near camelids (Fig. 3). Two Protypotherium specimens, however, have longer jaws, showing a combination of jaw length and hypsodonty more similar to many extant ungulates from open habitats. Interatherium specimens have an intermediate hypsodonty $(\mathrm{HI} \sim 3.3$; Table 2) but they show a wide range in the relative length of their jaws, which translates as a wide range of HPI values (0.8-1.3). Most of them show combinations of jaw length and hypsodonty similar to extant ungulates from both open and mixed habitats. Finally, the most hypsodont are two specimens of Hegetotherium ( $\mathrm{HI} \sim 7.8$; Table 2 ), comparable with Equus asinus $(\mathrm{HI} \sim 8.7)$. Their HPI values are very high (2.92 and 3.18), so their HPI are much higher than the threshold that separates open-habitat species from those of mixed habitats. However, there are no living species with such a short jaw combined with so high hypsodonty. Thus, they occupy an exclusive topleft region in the morphospace depicted by $\mathrm{HI}$ and JAW.

Among toxodontids, the specimens of Adinotherium are very hypsodont $(\mathrm{HI} \sim 4.9$; Table 2$)$, and their jaws length are variable, so their HPI are also very different (1.1, 2.2 and 1.8). All of them, however, show combinations of jaw length and hypsodonty similar to extant ungulates from open habitats. Nesodon specimens

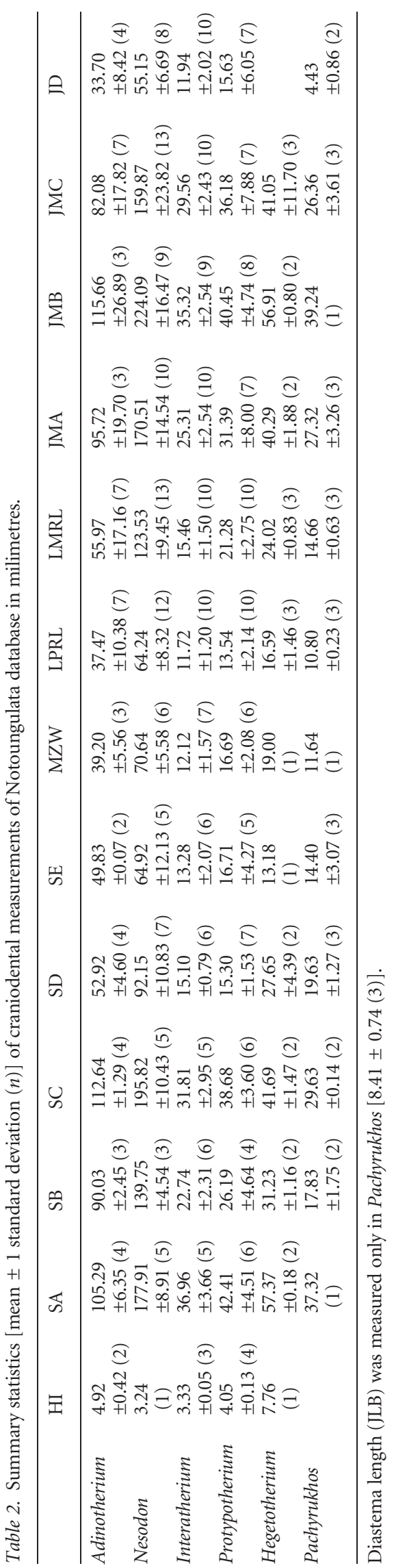


show HI values around 3.2 (Table 2) and their HPI ranges from 1.5 to 2.2 , so they are clearly over the limits of HI and HPI that separate species dwelling open habitat from those dwelling mixed or closed habitat. They lie on the left-bottom region in the morphospace depicted by HI and JAW, without overlapping with any extant ungulates, but surrounded by open-habitat camelids.

According to their HPI and HI values, most Santacrucian notoungulates foraged in open habitats (Fig. 3). Only three specimens of Interatherium show a combination of HI and JAW characteristic of living ungulates that forage in mixed habitats (but see Discussion and conclusions section).

\section{Inferences about diet}

All the Santacrucian notoungulates were treated as specimens from open or mixed habitats to perform the analyses about their feeding behaviour. Species from these habitats can be classified as grazers, mixed feeders or browsers.

The classification tree shown in Fig. 4 allowed to discover that the relative width of the muzzle (MZW) and the maximum width of mandibular angle (JMC) play an essential role in the adaptation of ungulates for feeding mainly on grass, allowing a very good characterization of grazers in comparison with other feeding groups (see Fig. 5). This tree correctly reclassifies $94.3 \%$ ( 83 of 88 ) of species involving only JMC

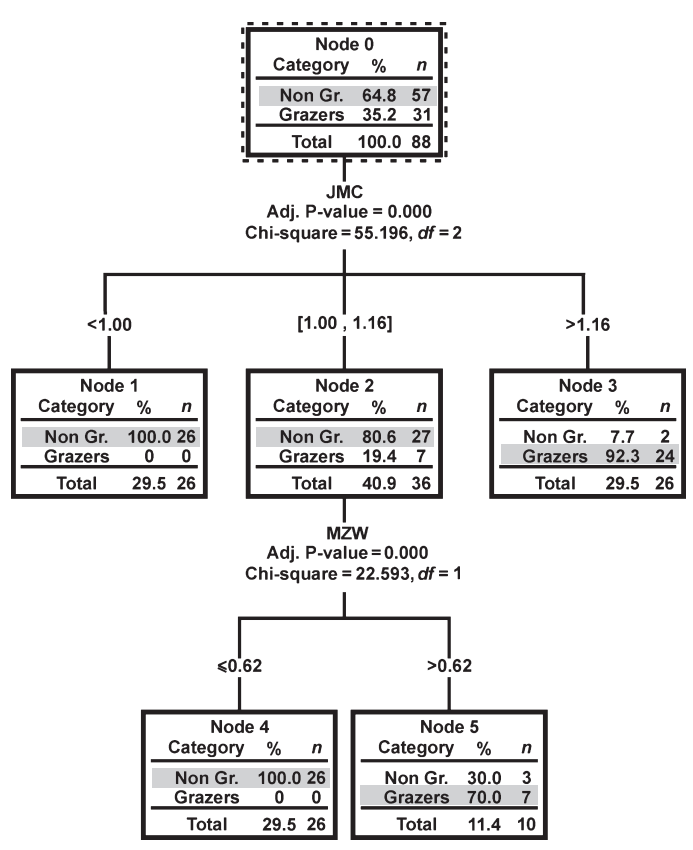

Fig. 4. Classification tree that permitted the discovery of the relationship between both the relative width of the muzzle (MZW) and the relative maximum width of mandibular angle (JMC), and the adaptation of ungulates for feeding on grass.

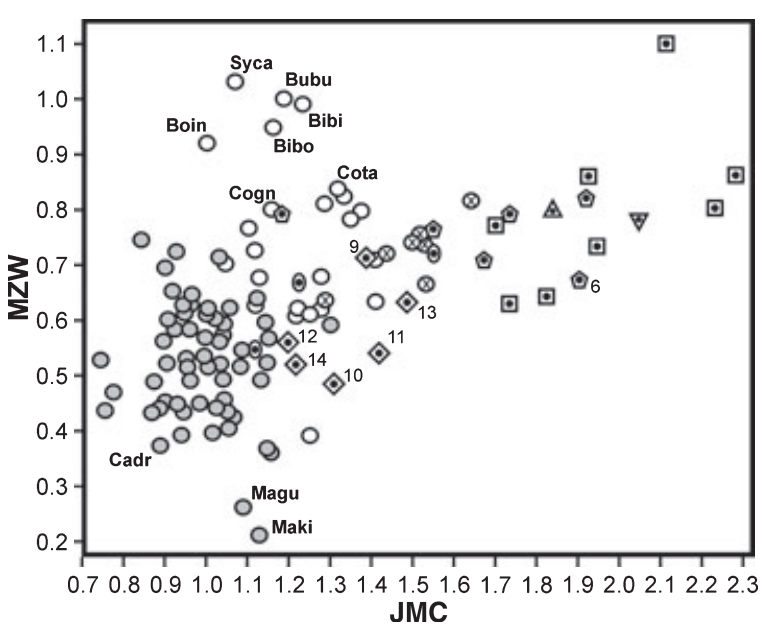

Fig. 5. Distribution of the 88 extant ungulates (circles), inhabitants of open and mixed habitats and 24 notoungulates (dotted symbols) in the morphospace depicted by MZW and JMC, which allows the morphological characterization of grazers (white circles) and nongrazers (grey circles). Notoungulata (dotted symbols): Interatherium (squares), Nesodon (rhombus), Protypotherium (pentagons), Hegetotherium (inverse triangles), Adinotherium (ovoids), Pachyrukhos (right-angled triangles). Extant ungulates: Equus species (crossed circles), Camelus dromedarius (Cadr), Madoqua guentheri (Magu), Madoqua kirkii (Maki), Connochaetes gnou (Cogn), Connochaetes taurinus (Cota), Bison bison (Bibi), Bos indicus (Boin), Syncerus caffer (Syca), Bubalus Bubalus (Bubu) and Bison bonasus (Bibo).

and MZW. The importance of these two morphological traits also became evident with discriminant analysis. Curiously enough, the discriminant function that involves the same two variables $(6.253 \mathrm{MZW}+5.886$ JMA - 10.197) reclassifies correctly the same percentage of species, $94.3 \%$.

Mendoza \& Palmqvist (2008) show that grazers have a wider muzzle than other ungulates from open habitats, and the few browsers that live in open habitats have some of the narrowest muzzles among ungulates. We show here that grazers also have a jaw with a wider mandibular angle than other ungulates from open and mixed habitats. The morphospace depicted by the relative width of the muzzle (MZW) and the maximum width of mandibular angle (JMC) allows a very good characterization of grazers in comparison with non-grazers (see Fig. 5).

Although grazers of the family Bovidae (order Artiodactyla) are characterized by wide muzzles, grazers of the family Equidae (order Perissodactyla) mainly have wide mandibular angles (see Fig. 5). Non-grazers in both groups show a common and relatively homogeneous pattern, characterized by both narrow muzzles and mandibular angles.

Santacrucian notoungulates share with equids, a wide mandibular angle (only those specimens for which MZW is also available appear in Fig. 5). Although in equids JMC ranges from 1.29 to 1.64 , in 
Interatherium it ranges from 1.70 to 2.28 , in Protypotherium JMC from 1.55 to 2.31, in Hegetotherium from 1.13 to 2.05 and in Pachyrukhos from 1.47 to 2.11. Notoungulates also share with bovids a wide muzzle. In fact, the highest value of MZW corresponds to an Interatherium specimen (see Fig. 5). According to its muzzle and mandibular angle width, Nesodon was the less-specialized genus in the consumption of grass, although specimens 9 and 13 have both the muzzle and the mandibular angle as wide as some equids (see Fig. 5).

Other traits also seem to be involved in the morphological patterns that adapt ungulates for feeding mainly grass. As shown in Fig. 6, the morphospace depicted by the depth of the mandibular angle (JMB) and the length of the paraoccipital process (SE) also allows a good characterization of grazers in comparison with non-grazers. Again, grazers from the families Bovidae and Equidae show some differences. Both increased the depth of the mandibular angle (JMB), but much more equids than bovids, and only bovids show a longer paraoccipital process (SE; see Fig. 6). Thus, non-grazer ungulates are again the group of species that show a common pattern, characterized by both a shallower mandibular angle and a shorter paraoccipital process than grazers. Notoungulates share both traits of grazers, a deeper mandibular angle (JMB) and a longer paraoccipital process (SE, see Fig. 6).

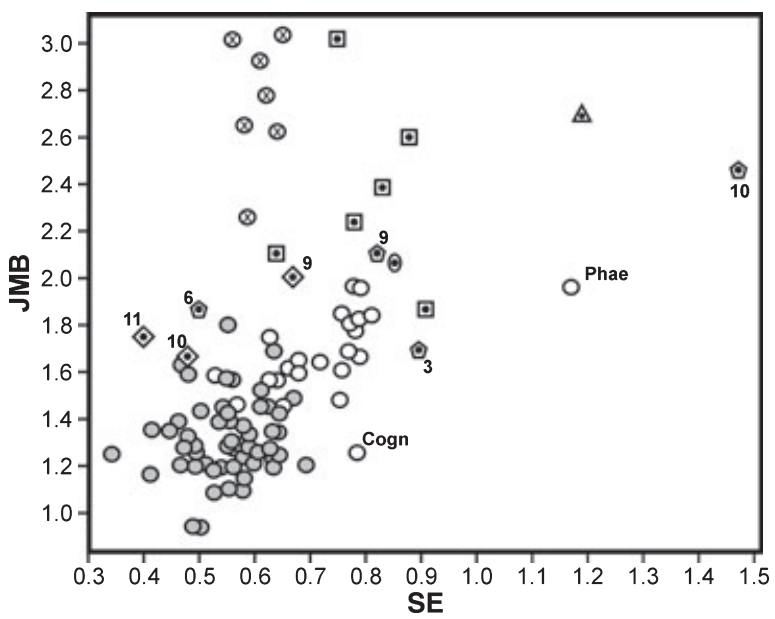

Fig. 6. Distribution of the 88 extant ungulates (circles) inhabitants of open and mixed habitats and 24 notoungulates (dotted symbols) in the morphospace depicted by JMB and SE, which allows the morphological characterization of grazers (white circles) and non-grazers (grey circles). Notoungulata (dotted symbols): Interatherium (squares), Nesodon (rhombus), Protypotherium (pentagons), Hegetotherium (inverse triangles), Adinotherium (ovoids) and Pachyrukhos (right-angled triangles). Extant ungulates: Equus species (crossed circles), Camelus dromedarius (Cadr), Madoqua guentheri (Magu), Madoqua kirkii (Maki), Connochaetes gnou (Cogn), Connochaetes taurinus (Cota), Bison bison (Bibi), Bos indicus (Boin), Syncerus caffer (Syca), Bubalus Bubalus (Bubu) and Bison bonasus (Bibo).
Among notoungulates, a specimen of Interatherium show the deepest mandibular angle, with a JMB value only found in equids. Other specimens show lower values of JMB, and SE values typical of living grazers. There are two specimens of notoungulates, however, with extreme SE values. A specimen of Protypotherium shows the longest paraoccipital process, but other specimen of the same genus (Proty 6; Fig. 6), however, has a paraoccipital process shorter than any grazer $(\mathrm{SE}=0.5)$. Its muzzle width is also similar to that of the non-grazers, but its mandibular angle is wider than that of any living non-grazers (Proty 6; Fig. 5). There is also a Pachyrukhos specimen with an extreme SE value, although its paraoccipital process is not much longer than that of the only grazer species of the family Suidae (Fig. 6).

JMB is not available for Nesodon specimens 12 and 14 , which are the closest to the living non-grazers in the morphospace depicted by MZW and JMC (Fig. 5). They could not be so represented in Fig. 6, but both specimens have SE values (0.4 and 0.6) typical of living non-grazers. Both JMB and SE are available, indeed for Nesodon 10 and 11, which also show SE values characteristic of non-grazer ungulates, and lower than any living grazer. According to their location in the morphospace depicted by MZW and JMC (Fig. 5), their feeding adaptations are not very clear, but taking also into account their location in the morphospace depicted by JMB and SE (Fig. 6), it seems more probable that both specimens were adapted for grazing and browsing. Neither JMB nor SE is available in specimen 13, but specimen 9 is also located with grazers (Fig. 6).

\section{Discussion and conclusions}

The feeding categories of grazing, mixed-feeding and browsing herbivores were initially characterized by Hofmann \& Stewart (1972), who correlated feeding behaviour with stomach anatomy. Several authors (Janis \& Ehrhardt 1988; Solounias \& Moelleken 1993; Janis 1995; Pérez-Barbería \& Gordon 1999; Mendoza et al. 2002) have used the correspondences between craniodental morphology and ecological adaptations. However, feeding and habitat morphological adaptations of the craniodental skeleton are not easily distinguishable. In fact, analyses considering the phylogenetic constraints performed by Pérez-Barbería et al. (2001) demonstrated that both habitat and diet are correlated.

The approach followed in this study was a hierarchical analysis identifying the correlation between morphology and habitat types, and then feeding 
behaviour between certain habitats, versus Spencer (1995), who evaluated habitats preference within diet categories.

High crown is the morphological trait that have been most frequently considered as indicative of feeding behaviour in ungulates in relation to grass consumption, and correlated with the spread of grass land habitats (for extensive overviews on the subject, see Janis 1995; MacFadden 2000; Strömberg 2006; Billet et al. 2009; Reguero et al. 2010). Van Valen (1960) provided the first quantitative approach to these relationships, defining an HI. It was not until the late 1980s that a comparative study by Janis (1988) tested this hypothesis in living ungulates, hyraxes and the African elephant. Further research (Janis 1995) led this author to conclude that $\mathrm{HI}$ better indicates open-habitat environmental preference than determining grass consumption in extinct ungulates.

More recently, after removing phylogenetic effects, Williams \& Kay (2001) found that tooth crown height in rodents and ungulates was positively correlated with the proportion of monocots (primarily grass) in the diet and was negatively correlated with foraging height preferences. In a study on fossil equids and phytoliths, Strömberg (2006) showed that care should be taken when interpreting diet/habitat from hypsodonty of extinct species. Moreover, Mendoza \& Palmqvist (2008) found that, in ungulates, there is no direct relationship between the degree of hypsodonty and the amount of grass consumed, except for the correspondence between grazing and dwelling in open habitats. These authors also proposed that hypsodonty represents a 'key adaptation' of ungulates for feeding in open environments, where the vegetation that grows at ground level accumulates airborne grit (Mendoza \& Palmqvist 2008). In a recent contribution, Billet et al. (2009) summarized the factors that favoured increasing hypsodonty as two alternative hypotheses, named increasing chewing effort and increase of abrasives consumed.

Generating a hypothesis about habitat preferences was the first step in our analysis. In Mendoza \& Palmqvist (2008), all ungulates that dwell in open or mixed habitat has an $\mathrm{HI}>2$, and the $\mathrm{HI}$ that allows distinguishing open habitats from mixed habitats increases with the relative length of diastema (JLB). In this contribution, we faced the problems that most notoungulates studied do not have diastema, and therefore JLB was not applicable to our sample, and for Pachyruchos - the only one with a diastema - there are not specimens available in the collection studied to calculate $\mathrm{HI}$ following the procedure described above. Applying the same knowledge-discovery techniques as that of Mendoza \& Palmqvist (2008), we found that the other measurement that shows a similar pattern is the length of the jaw (JAW). Thus, there are species adapted to open habitats with low hypsodonty, like camels, but all of them have a short jaw, and there are hypsodont species dwelling mixed habitats, which have jaws that are always long.

Using the relative length of the jaw and the HI, we defined a HPI, which allows the inference of whether an ungulate species is more likely to dwell open or mixed habitats. Using that index, combined with the $\mathrm{HI}$, it is possible to characterize the species adapted to forage in open, mixed and closed habitats. Only openhabitat highly selective browsers feeding on heavy shrubbery such as Madoqua guentheri and Madoqua kirkii the dik-diks and Oreamnos americanus the Mountain Goat, which is found only on the steep slopes of Rocky Mountain, and those species dwelling open but water-associated habitats such as Ozotoceros bezoarticus the pampas deer and Waterbucks and another three species of the genus Kobus, which have a HPI lower that 1, cannot be distinguished from those species dwelling mixed habitats (Fig. 3).

According to their HPI and HI values and the region that they occupy in the morphospace depicted by HI and JAW, all Santacrucian notoungulates foraged in open habitats (Fig. 3). With the exception of two specimens of Hegetotherium, they show a combination of $\mathrm{HI}$ and JAW that is not very different from the extant ungulate species dwelling open habitats. Hegetotherium specimens $(\mathrm{HI}=7.76)$ are almost as hypsodont as the wild ass (Equus asinus, $\mathrm{HI}=8.73$ ), but their jaws are much shorter, so they occupy a region of the morphospace depicted by HI and JAW, which is not occupied by any extant ungulate species (see Fig. 3). In the case of Interatherium, it could have also been from mixed or water-associated open habitats.

Following Tauber (1997a), one peculiarity of the Santa Cruz Formation is the presence of indicators of different climatic and environmental conditions. On one side, the occurrence of Primates, and echimyid and erethizontid rodents has been interpreted as indicators of warm and humid conditions, and forests (Vucetich 1986; Pascual \& Ortiz-Jaureguizar 1990). On the other hand, the diversity of armadillos (Vizcaíno et al. 2006) and the presence of probable palaeodunes (Bown \& Larriestra 1990), gypsum crystals, mud cracks and other sedimentological features (Tauber 1997a) suggest the existence of open environments in relatively dry conditions. Additionally, the Santa Cruz Formation rocks are, to a great extent, a sequence of superimposed mudstones of volcaniclastic origin, although some relatively unaltered tuffs also occur (Bown \& Fleagle 1993). The consequent abundance of abrasive volcanic particles may account for much of the grit that the herbivores must have 
ingested with the food (Kay et al. 1999). The knowledge of the evolution of the early Miocene palaeoflora of Patagonia (Barreda \& Palazzesi 2007) is coherent with this scenario, confirming the existence of both close and open environments. Although forests remained, probably developing riparian or gallery forests, across extra-Andean Patagonia until about the middle Miocene, in the late early Miocene drier conditions would have prevailed in lowland areas, and the contraction of humid elements coincides with the expansion of xerophytic taxa.

The next step in our research was to characterize the feeding craniodental traits of ungulates correlated to dwelling open or mixed habitats. The features distinguishing grazers from browsers probably relate to the different physical demands of feeding on grass versus leaves. Muzzle width has been considered important for the inference of alimentary styles in extinct herbivores (Solounias \& Moelleken 1993; Janis 1995; Solounias et al. 1995). Grass is in general more fibrous, and requires a greater intake and degree of mastication than leaves. Grazers show wider muzzles than browsers, which allow the intake of large bites (bulk feeding) while grazing (Owen-Smith \& Novellie 1982). Grazers also have bigger masseter muscles than browsers, reflected in a larger and deeper angle of the jaw, and a longer masseteric fossa on the skull (Axmacher \& Hofmann 1988; Clauss et al. 2008). Browsers are selective feeders (Gordon \& Illius 1988), have a narrower muzzle than grazers, which is useful for feeding selectively on certain plants or parts of plants (Solounias et al. 1988; Solounias \& Moelleken 1993).

According to our results, non-grazers show a common and relatively homogeneous morphological pattern, which characterize them in comparison with grazers. They show a narrow muzzle, a shallow and narrow mandibular angle, and a short paraoccipital process. Thus, in the four-dimensional morphospace defined by these variables, all the non-grazers would occupy a region around 1 of the 16 vertices of a tesseract (the four dimensional analogue of a cube) containing all the species. Grazers are not so homogeneous, as there are some differences in the way that bovids and equids adapted to feed mainly on grass. Both groups widened their muzzle, but bovids much more than equids, which mainly widened their mandibular angle (see Fig. 5). Both groups also increased the depth of the mandibular angle, but much more equids than bovids, and only bovids enlarged the paraoccipital process (see Fig. 6).

Among the assemblage of notoungulates of the Santa Cruz Formation, the typotheres Interatherium, Protypotherium, Hegetotherium and Pachyrukhos show some characteristic of living grazers, i.e. a wide muzzle, an extremely wide and deep mandibular angle, and a large paraoccipital process (see Figs 5, 6). Thus, they show a morphological pattern similar to the one of those extant ungulates adapted to feed mainly on grass, and far from the one of those than feed mainly on browse, or grass and browse depending of availability. Typotheres, however, do not fit with the general pattern observed in extant ungulates, as small forms are browsers (Pérez-Barbería \& Gordon 2001). Based on the incisors morphology and implantation, Tauber (1996) proposed that the larger species of Protypotherium ( $P$. australe) was adapted to forage on harder grasses than the other two (P. praerutilum and $P$. attenuatum). Among hegetotherids, Reguero et al. (2007) concluded that, according to their muzzle and masseteric morphology, Oligocene pachyrukines were selective grazers.

Rodent-like typotheres (especially Interatherium and Pachyrukhos) exhibit morphological features that exaggerate the patterns shown by modern grazing ungulates, and some (especially Hegetotherium) exaggerated even more the features (HI) that indicate dwelling in open habitats. The last two statements suggest that both the peculiar general rodent-like morphology and other than feeding habits, like digging, may be influencing their position in the respective morphospaces. A locomotory morphofunctional analysis by Elissamburu (2004), comparing with living caviomorph rodents, reveals that certain indices allow to characterize Pachyrukhos and Protypotherium as occasional diggers and Interatherium and Hegetotherium as diggers. Billet et al. (2009) proposed that theirs 'grit hypothesis' applied to other notoungulates like the mesotheriid Trachytherus from the Oligocene of Bolivia, which could be a fossorial animal that ingested a great quantity of exogenous grit along with its food (Shockey et al. 2007). It is known that, in caviomorph rodents, adaptation to digging habits also correlates with craniodental traits (Verzi \& Olivares 2006) and that digging behaviour usually implies the ingestion of large quantities of abrasive soil elements playing a role in the development of hypsodonty in xenarthrans (Bargo et al. 2006). As it was mentioned above, abundance of abrasive volcanic particles in the Santa Cruz Formation may account for much of the grit that the herbivores must have ingested with the food. Considering their small body size, general likeness with nonungulate herbivores (glires, hyraxes), that they have no close relatives among living ungulates and that they do not match exactly the same morphospace, other living herbivores analogues should be used in further analyses to contrast these inferences.

The toxodontid Adinotherium also shows the craniodental morphology characteristic of living grazers, i.e. a wide muzzle, an extremely wide and deep mandibular angle, and a large paraoccipital process 
(see Figs 5, 6). Nesodon, however, seems to be less specialized in the consumption of grass than the others notoungulates. Most specimens of Nesodon are similar to living ungulates classified as a mixed feeder, although there are at least two specimens of Nesodon showing a morphological pattern close to the typical one of living equids. Toxodontids similarity to other ungulates has been highlighted since the earliest studies of Patterson (1932). They attained body sizes comparable with living ungulates and share the morphospace occupied by living grazing and mixed-feeders ungulates in open habitats.

There are some other traits, which have not been represented here, that also seem to be involved in the morphological patterns that adapt ungulates for feeding mainly on grass. The posterior jaw length (JMA), for example, also allows a good characterization of grazers in comparison with non-grazers when it is represented in combination with the length of the paraoccipital process (SE). Non-grazer ungulates are characterized by both a shorter posterior jaw and paraoccipital process. Among notoungulates, only Nesodon's three specimens occupy a region between grazers and non-grazers, whereas the fourth is located in the middle of typical grazers.

Grazers also show a longer posterior portion of the skull (SC), but this is the only trait that Santacrucian notoungulates do not share with them. Phacochoerus aethiopicus the warthog, the only grazer of family Suidae, is also the only extant grazer that shares a short posterior portion of the skull (SC) with notoungulates.

In summary, our results indicate that the Santacrucian notoungulates show similar, or even exaggerated, morphological patterns to extant ungulates adapted for feeding mainly on grasses, and far from those mixed-feeders or browsers. This implies interesting consequences in the consideration of the evolution of craniodental traits to grazing habits in ungulates. Following Janis et al. (2004), it was not until the start of the late Miocene, around $10 \mathrm{Ma}$, that ungulates with morphologies consistent with more specialized grazing adaptations appeared. The fact that typotheres could be classified as grazers implies that native South American ungulates evolved grazing specializations at least by the late-early Miocene at ca. $16 \mathrm{MA}$, i.e. much before than extant main lineages in northern hemisphere. This hypothesis had been proposed before on the basis that hypsodonty among ungulates has its first appearance in South American lineages rather than in northern hemisphere ungulates (see Patterson \& Pascual 1972; MacFadden 2000; Billet et al. 2009).

Using species from two living orders of ungulates, artiodactyls and perissodactyls, as a reference sample, to infer the ecological behaviours of a third extinct order of ungulates, we are assuming that notoungulates resolved the same biomechanical problems with convergent morphological solutions. However, the majority of living ungulates are ruminant artiodactyls, and quantitative correlations of morphology and behaviour derived from ruminants may not be directly applicable to other types of ungulates, although general qualitative observations may still hold true (Janis 2008). This is particularly remarkable when dealing with forms that developed so different morphologies as typotheres. Although a validation of our results through other approaches (e.g. morphofunctional, biomechanical, biogeochemical and tooth micro- and mesowear analyses) remains pending, the fact that different morphological traits consistently point to the same adaptations strengthens them.

Acknowledgements. - We thank the following persons and institutions: Dirección de Patrimonio Cultural, and Museo Regional Provincial Padre M. J. Molina (Río Gallegos, Santa Cruz Province) for permission and support for the fieldwork; vertebrate palaeontological collections managers Marcelo Reguero from MLP, Alejandro Kramarz from MACN, John Flynn from AMNH and Walter Joyce from YPM; Nestor Toledo for the illustrations of Fig. 2; Annat Habber and the reviewers Darin Croft and Guilleume Billet for the valuable suggestions that improved the work. The study of the US/YPM collection was partially funded by the John H Ostrom Research Fund. This is a contribution to the projects PICT 26219 of the Agencia Nacional Promoción Científica y Tecnológica, PIP 1054 of the Consejo Nacional de Investigaciones Científicas y Técnicas and N747 of the Universidad Nacional de La Plata.

\section{References}

Ameghino, F. 1887: Enumeración sistemática de las especies de mamíferos fósiles coleccionados por Carlos Ameghino en los terrenos eocenos de la Patagonia austral y depositados en el Museo La Plata. Boletín del Museo La Plata 1, 1-26.

Ameghino, F. 1889: Contribución al conocimiento de los mamíferos fósiles de la República Argentina. Actas de la Academia Nacional de Ciencias de Córdoba 6, 1-1027.

Ameghino, F. 1894: Enumération synoptique des espèces de mammiferes fossiles des formations éocènes de Patagonie. Boletín De La Academia De Ciencias De Córdoba 13, 259-452.

Ameghino, F. 1907: Les toxodontes à cornes. Anales del Museo Nacional de Historia Natural de Buenos Aires 16, 4991.

Axmacher, H. \& Hofmann, R.R. 1988: Morphological characteristics of the masseter muscle of 22 ruminant species. Journal of Zoology 215, 463-473.

Bargo, M.S., De Iuliis, G. \& Vizcaíno, S.F. 2006: Hypsodonty in Pleistocene ground sloths. Acta Palaeontologica Polonica 51, 5361.

Barreda, V. \& Palazzesi, L. 2007: Patagonian vegetation turnovers during the paleogene-early neogene: origin of arid-adapted floras. Botanical Review 73, 31-50.

Billet, G. 2010: New observations on the skull of Pyrotherium (Pyrotheria, Mammalia) and new phylogenetic hypotheses on South American ungulates. Journal of Mammalian Evolution 17, 21-59.

Billet, G., Blondel, C. \& de Muizon, C. 2009: Dental microwear analysis of notoungulates (Mammalia) from Salla (Late Oligocene, Bolivia) and discussion on their precocious hypsodonty. Palaeogeography, Palaeoclimatology, Palaeoecology 274, 114124. 
Bond, M. 1986: Los ungulados fósiles de Argentina: evolución y paleoambientes. In Simposio 'Evolución de los Vertebrados Cenozoicos', IV cogreso argentino de paleontologia y bioestratigrafia. Actas 2, 187-190, Mendoza, 23-27 November.

Bond, M. 1999: Quaternary native ungulates of Southern South America. A synthesis. In Tonni, E.P. \& Cione, A.L. (eds): Quaternary of South America and Antarctic Peninsula, Vol. 12, 177205. A.A. Balkema, Rotterdam.

Bond, M., Cerdeño, E. \& López, G. 1995: Los ungulados nativos de América del Sur. In Alberdi, M.T., Leone, G. \& Tonni, E.P. (eds): Evolución biológica y climática de la región Pampeana durante los últimos cinco millones de años. Un ensayo de correlación con el Mediterráneo occidental, 259-275. CSIC, Madrid.

Bondesio, P. 1986: Lista sistematica de los vertebrados terrestres del cenozoico de argentina. In Simposio 'Evolución de los Vertebrados Cenozoicos', IV cogreso argentino de paleontologia y bioestratigrafia. Actas 2, 187-190, Mendoza, 23-27 November.

Bown, T.M. \& Fleagle, J.G. 1993: Systematics, biostratigraphy, and dental evolution of the Palaeothentidae, later Oligocene to early-middle Miocene (Deseadan-Santacrucian) caenolestoid marsupials of South America. Journal of Paleontology 67, 1-76.

Bown, T.M. \& Larriestra, C.N. 1990: Sedimentary paleoenvironments and fossil platyrrhinae localities, Miocene Pinturas Formation, Santa Cruz Province, Argentina. Journal of Human Evolution 19, 87-119.

Breiman, L., Friedman, J.H., Olshen, R.A. \& Stone, C.J. 1984: Classification and Regression Trees. CRC Press, Florida.

Cifelli, R.L. 1985: South American ungulate evolution and extinction. In Stehli, F.G. \& Webb, S.D. (eds): The Great American Biotic Interchange, 249-266. Plenum Press, New York.

Cifelli, R.L. 1993: The phylogeny of the native South American ungulates. In Szalay, F.S., Novacek, M.J. \& Mckenna, M.C. (eds): Mammals Phylogeny: Placentals, 195-216. Springer-Verlag, New York and London.

Cios, K., Pedrycz, W. \& Swiniarski, R. 1998: Data Mining Methods for Knowledge Discovery. Kluwer, Boston.

Clauss, M., Hofmann, R.R., Streich, W.J., Fickel, J. \& Hummel, J. 2008: Higher masseter muscle mass in grazing than in browsing ruminants. Oecologia 157, 377-385.

Croft, D.A. 1999: Placentals: endemic South American ungulates. In Singer, R. (ed.): The Encyclopedia of Paleontology, 890-906. Fitzroy-Dearborn, Chicago.

Croft, D.A. \& Weinstein, D. 2008: The first application of the mesowear method to endemic South American ungulates (Notoungulata). Palaeogeography, Palaeoclimatology, Palaeoecology $269,103-114$

Elissamburu, A. 2004: Morphometric and morphofunctional analysis of the apendicular skeleton of Paedotherium (Mammalia, Notoungulata). Ameghiniana 41, 363-380.

Gordon, I.J. \& Illius, A.W. 1988: Incisor arcade structure and diet selection in ruminants. Functional Ecology 2, 15-22.

Hofmann, R.R. \& Stewart, D.R.M. 1972: Grazer or browser: a classification based on the stomach structure and feeding habits of East African ruminants. Mammalia 36, 226-240.

Janis, C.M. 1988: An estimation of tooth volume and hypsodonty indices in ungulate mammals, and the correlation of these factors with dietary preference. In Russell, D.E., Santoro, J.P. \& Sigoneau-Russell, D. (eds): Teeth Revisited: Proceedings of the VII International Symposium on Dental Morphology, Vol. 53, 367387. Mém. Mus. natn. Hist. nat., Paris.

Janis, C.M. 1990a: Correlation of cranial and dental variables with body size in ungulates and macropodoids. In Damuth, J. \& MacFadden, B.J. (eds): Body Size in Mammalian Paleobiology: Estimation and Biological Implications, 255-300. Cambridge University Press, Cambridge.

Janis, C.M. 1990b: Correlation of cranial and dental variables with dietary preferences in mammals: a comparison of macropodoids and ungulates. Memoirs of the Queensland Museum 28, 349-366.

Janis, C.M. 1995: Correlations between craniodental morphology and feeding behavior in ungulates: reciprocal illumination between living and fossil taxa. In Thomason, J.J. (ed.): Functional Morphology in Vertebrate Paleontology, 76-98. Cambridge University Press, Cambridge.
Janis, C.M. 2008: An evolutionary history of browsing and grazing ungulates. In Gordon, I.J. \& Prins, H.H.T. (eds): The Ecology of Browsers and Grazers, 21-45. Springer-Verlag, Berlin.

Janis, C.M. \& Ehrhardt, D. 1988: Correlation of relative muzzle width and relative incisor width with dietary preference in ungulates. Zoological Journal of the Linnean Society 92, 267-284.

Janis, C.M., Damuth, J. \& Theodor, J.M. 2004: The species richness of Miocene browsers, and implications for habitat type and primary productivity in the North American grassland biome. Palaeogeography, Palaeoclimatology, Palaeoecology 207, 371-398.

Kay, R.F., Madden, R.H., Vucetich, M.G., Carlini, A.A., Mazzoni, M.M., Re, G.H., Heizler, M. \& Sandeman, H. 1999: Revised Geochronology of the Casamayoran South American Land Mammal Age: climatic and Biotic Implications. Proceedings of the National Academy of Sciences of the United States of America 96, 13235-13240.

Larose, D.T. 2004: Discovering Knowledge in Data: An Introduction to Data Mining. John Wiley \& Sons, New York.

MacFadden, B.J. 2000: Cenozoic mammalian herbivores from the Americas: reconstructing ancient diets and terrestrial communities. Annual Review of Ecology and Systematics 31, 33-59.

Madden, R.H. 1997: A new toxodontid notoungulate. In Kay, R.F., Madden, R.H., Cifelli, R.L. \& Flynn, J.J. (eds): Vertebrate Paleontology in the Neotropics: The Miocene Fauna of La Venta, 355381. Smithsonian Institution Press, Washington DC.

Martin, P.S. \& Steadman, D.W. 1999: Prehistoric extinctions on islands and continents. In MacPhee, R.D.E. (ed.): Extinctions in Near Time: Causes, Contexts and Consequences, 17-56. Kluwer/Plenum, New York.

Mendoza, M. 2007: Decision trees: a machine learning methodology for characterizing morphological patterns resulting from ecological adaptations. In MacLeod, N. (ed.): Automated Recognition of Biological Objects, 261-276. Systematics Association's Special Volume, UK.

Mendoza, M. \& Palmqvist, P. 2006: Characterizing adaptive morphological patterns related to diet in Bovidae (Mammalia: Artiodactyla). Acta Zoologica Sinica 52, 988-1008.

Mendoza, M. \& Palmqvist, P. 2008: Hypsodonty in ungulates: an adaptation for grass consumption or for foraging in open habitat? Journal of Zoology 274, 134-142.

Mendoza, M., Janis, C.M. \& Palmqvist, P. 2002: Characterizing complex craniodental patterns related to feeding behaviour in ungulates: a multivariate approach. Journal of Zoology 258, 223246.

Mendoza, M., Janis, C.M. \& Palmqvist, P. 2005: Ecological patterns in the trophic-size structure of large mammal communities: a 'taxon-free' characterization. Evolutionary Ecology Research 7, 505-530.

Michie, D., Spiegelhalter, D.J. \& Taylor, C.C. 1994: Machine learning, neural \& statistical classification. Ellis Horwood, New York.

Mones, A. 1982: An equivocal nomenclature: what means hypsodonty? Paläontologische Zeitschrift 56, 107-111.

Owen-Smith, N. \& Novellie, P. 1982: What should a clever ungulate eat? The American Naturalist 119, 151-178.

Pascual, R. \& Ortiz-Jaureguizar, E. 1990: Evolving climates and mammal faunas in Cenozoic South America. Journal of Human Evolution 19, 23-60.

Patterson, B. 1932: The auditory region of the Toxodontia. Field Museum of Natural History, Geological Series 6, 1-27.

Patterson, B. \& Pascual, R. 1968: The fossil mammal fauna of South America. Quarterly Review of Biology 43, 409-451.

Patterson, B. \& Pascual, R. 1972: The fossil mammal fauna of South America. In Keast, A., Erk, F.C. \& Glass, B. (eds): Evolution, Mammals, and Southern Continents, 247-309. University of New York State Press, Albany.

Pérez-Barbería, F.J. \& Gordon, I.J. 1999: The functional relationship between feeding type and jaw and cranial morphology in ungulates. Oecologia 118, 157-165.

Pérez-Barbería, F.J. \& Gordon, I.J. 2001: Relationships between oral morphology and feeding style in the ungulata: a phylogenetically controlled evaluation. Proceedings of the Royal Society of London, Series B: Biological Sciences 268, 1023-1032. 
Pérez-Barbería, F.J., Gordon, I.J. \& Nores, C. 2001: Evolutionary transitions among feeding styles and habitats in ungulates. Evolutionary Ecology Research 3, 221-230.

Reguero, M.A., Dozo, M.T. \& Cerdeño, E. 2007: A poorly known rodentlike mammal (Pachyrukhinae, Hegetotheriidae, Notoungulata) from the Deseadan (Late Oligocene) of Argentina. Paleoecology, biogeography, and radiation of the rodentlike ungulates in South America. Journal of Paleontology 81, 13011307.

Reguero, M.A., Candela, A.M. \& Cassini, G.H. 2010: Hypsodonty and body size in rodent-like notoungulates. In Madden, R.H., Carlini, A.A., Vucetich, M.G. \& Kay, R.F. (eds): The Paleontology of Gran Barranca: Evolution and Environmental Change through the Middle Cenozoic of Patagonia, 358-367. Cambridge University Press, Cambridge.

Scott, W.B. 1912: Mammalia of the Santa Cruz beds. In Nàgele, E. (ed.): Toxodonta of the Santa Cruz Beds, Vol. VI, 111-300. Princeton University, Stuttgart.

Scott, W.B. 1937: A History of Land Mammals in the Western Hemisphere, 2nd edn. Macmillan, New York.

Shockey, B.J., Croft, D.A. \& Anaya, F. 2007: Analysis of function in the absence of extant functional homologues: a case study using mesotheriid notoungulates (Mammalia). Paleobiology 33, 227247.

Simpson, G.G. 1936: Structure of a primitive Notoungulate cranium. American Museum Novitates 824, 1-31.

Simpson, G.G. 1967: The beginning of the age of mammals in South America. Part II. Bulletin of the American Museum of Natural History 137, 1-260.

Sinclair, W.J. 1909: Mammalia of the Santa Cruz beds. In Nàgele, E. (ed.): Typotheria of the Santa Cruz Beds, Vol. VI, 1-110. E. Schweizerbart'sche Verlagshandlung, Stuttgart.

Solounias, N. \& Dawson-Saunders, B. 1988: Dietary adaptations and paleoecology of the Late Miocene ruminants from Pikermi and Samos in Greece. Palaeogeography, Palaeoclimatology, Palaeoecology 65, 149-172.

Solounias, N. \& Moelleken, S.M.C. 1993: Dietary adaptation of some extinct ruminants determined by premaxillary shape. Journal of Mammalogy 74, 1059-1071.

Solounias, N., Teaford, M. \& Walker, A. 1988: Interpreting the diet of extinct ruminants: the case of a non-browsing giraffid. Paleobiology 14, 287-300.

Solounias, N., Moelleken, S.M.C. \& Plavcan, J.M. 1995: Predicting the diet of extinct bovids using masseteric morphology. Journal of Vertebrate Paleontology 15, 795-805.
Spencer, L.M. 1995: Morphological correlates of dietary resource partitioning in the African Bovidae. Journal of Mammalogy 76, 448-471.

Strömberg, C.A.E. 2006: Evolution of hypsodonty in equids: testing a hypothesis of adaptation. Paleobiology 32, 236-258.

Tauber, A.A. 1996: Los representantes del género Protypotherium (Mammalia, Notoungulata, Interatheridae) del Mioceno Temprano del sudoeste de la Provincia de Santa Cruz, República Argentina. Academia Nacional de Ciencias 95, 3-29.

Tauber, A.A. 1997a: Biostratigraphy of the Santa Cruz Formation (Lower Miocene) in southeastern Patagonia. Ameghiniana 34, 413-426.

Tauber, A.A. 1997b: Palaeoecology of the Santa Cruz Formation (Lower Miocene) in the southeast border of Patagonia. Ameghiniana 34, 517-529.

Townsend, K.E.B. \& Croft, D.A. 2008: Diets of notoungulates from the Santa Cruz Formation, Argentina: new evidence from enamel microwear. Journal of Vertebrate Paleontology 28, 217230.

Van Valen, L. 1960: A functional index of hypsodonty. Evolution $14,531-532$

Verzi, D.H. \& Olivares, A.I. 2006: Craniomandibular joint in South American burrowing rodents (Ctenomyidae): adaptations and constraints related to a specialized mandibular position in digging. Journal of Zoology 270, 488-501.

Vizcaíno, S.F., Bargo, M.S., Kay, R.F. \& Milne, N. 2006: The armadillos (Mammalia, Xenarthra, Dasypodidae) of the Santa Cruz Formation (early-middle Miocene): an approach to their paleobiology. Palaeogeography, Palaeoclimatology, Palaeoecology 237, 255-269.

Vizcaíno, S.F., Bargo, M.S., Kay, R.F., Fariña, R.A., Di Giacomo, M., Perry, J.M., Prevosti, F., Toledo, N., Cassini, G.H. \& Fernicola, J.C. 2010: A baseline paleoecological study for the Santa Cruz Formation (late-early Miocene) at the Atlantic coast of Patagonia, Argentina. Palaeogeography, Palaeoclimatology, Palaeoecology 29, 507-519.

Vucetich, M.G. 1986: Historia de los roedores y primates en Argentina: su aporte al conocimiento de los cambios ambientales durante el Cenozoico. In Simposio 'Evolución de los Vertebrados Cenozoicos', IV cogreso argentino de paleontologia y bioestratigrafia. Actas 2, 157-165, Mendoza, 23-27 November.

Williams, S.H. \& Kay, R.F. 2001: A comparative test of adaptive explanations for hypsodonty in ungulates and rodents. Journal of Mammalian Evolution 8, 207-229. 